\title{
Partial purification and characterization of intracellular proteinases from Lactococcus lactis subsp lactis MG1363
}

\author{
LStepaniak ${ }^{1}, \mathrm{M}$ Gobbetti ${ }^{2}$, PF Fox* \\ Department of Food Chemistry and Food Biotechnology Centre, \\ University College, Cork, Ireland
}

(Received 28 February 1996; accepted 19 August 1996)

\begin{abstract}
Summary - Three caseinolytic proteinases (P1, P2, P3) were isolated from the cytoplasm of plasmid-free Lactococcus lactis subsp lactis MG1363 by sequential chromatography on DEAE-cellulose, Sephacryl 200, CM-cellulose, Phenyl Sepharose or hydroxyapatite and MonoQ ion exchanger. Minor caseinolytic fractions were separated during successive purification steps and the final preparations, although free from aminopeptidase activities, showed impurities by sodium dodecyl sulphate polyacrylamide gel electrophoresis (SDS-PAGE), indicating autolysis or a very complex caseinolytic system. Proteinase $P 1$ was a dimer with molecular mass $\left(M_{s}\right)$ of $c a 66 \mathrm{kDa}$ by SDS-PAGE and $124 \mathrm{kDa}$ by gel filtration and it was most sensitive to EDTA. Proteinase P2 $\left(\mathrm{M}_{\mathrm{s}} \mathrm{ca} 68 \mathrm{kDa}\right.$ by SDS-PAGE and $64 \mathrm{kDa}$ by gel filtration) and $\mathrm{P} 3\left(\mathrm{M}_{\mathrm{s}} \mathrm{ca} 52 \mathrm{kDa}\right.$ SDS-PAGE and $47 \mathrm{kDa}$ by gel filtration) were strongly inhibited by phenylmethylsulfonyl fluoride. Proteinase $\mathrm{P} 1$ was most active at $\mathrm{pH} 7.0$ and $35^{\circ} \mathrm{C}$, while proteinases P2 and P3 had optima at pH 7.5 and $45^{\circ} \mathrm{C}$. Urea-PAGE of digests of $\alpha$ - or $\beta$-casein showed differences in the peptide pattern released by the three proteinases after 6 or $20 \mathrm{~h}$ incubation. The peptides released by $\mathrm{P} 1, \mathrm{P} 2$ and $\mathrm{P} 3$ were also different from those produced by a crude preparation of the cell envelope-associated proteinase from $L$ lactis subsp lactis 712 , the parental strain of $L$ lactis subsp lactis MG1363. Reverse-phase fast protein liquid chromatography also showed differences between peptides released from $\alpha_{\mathrm{s} 1}$-casein by P1, P2 and P3.
\end{abstract}

\section{intracellular proteinase / Lactococcus lactis}

Résumé - Purification partielle et caractérisation de protéinases intracellulaires de Lactococcus lactis ssp lactis MG 1363. Trois protéinases caséolytiques (P1, P2, P3) ont été isolées du cytoplasme sans plasmide de Lactococcus lactis ssplactis MG1363 par chromatographie séquentielle sur cellulose DEAE, Sephacryl 200, CM-cellulose, Phenyl Sepharose ou hydroxyapatite et échange d'ions MonoQ. Les fractions caséinolytiques mineures ont été séparées lors de ces étapes de purifi-

\footnotetext{
${ }_{1}^{1}$ Permanent address: Department of Food Science, Agricultural University of Norway, Ås, Norway.

${ }^{2}$ Permanent address: Department of Dairy Microbiology, University of Perugia, Italy.

* Correspondence and reprints.
} 
cation successives, puis les préparations finales, bien que sans activité aminopeptidasique, ont montré des impuretés par SDS-PAGE, indiquant une autolyse ou un système caséolytique très complexe. La protéinase P1 était un dimère (masse moléculaire d'environ $66 \mathrm{kDa}$ par SDS PAGE et $124 \mathrm{kDa}$ par gel filtration) et elle était la plus sensible à l'EDTA. Les protéinases P2 (masse moléculaire d'environ $68 \mathrm{kDa}$ par SDS PAGE et $64 \mathrm{kDa}$ par gel filtration) et $\mathrm{P} 3$ (masse moléculaire d'environ $52 \mathrm{kDa}$ par SDS PAGE et $47 \mathrm{kDa}$ par gel filtration) étaient fortement inhibées par du phényl méthyl sulfonyl fluorure. La protéinase $\mathrm{P} 1$ était plus active à $\mathrm{pH} 7,0$ et $35^{\circ} \mathrm{C}$, tandis que les protéinases $\mathrm{P} 2$ et $P 3$ avaient un optimum à pH 7,5 et $45^{\circ} \mathrm{C}$. L'électrophorèse urée PAGE d'hydrolysats des caséines $\alpha$ et $\beta$ a montré des différences dans le profil peptidique libéré par les trois protéinases après 6 ou 20 heures d'incubation. Les peptides relargués par P1, P2 et P3 étaient également différents de ceux produits par une préparation brute de protéinases associées à l'enveloppe cellulaire de L lactis ssp lactis MG 712, issu de L lactis ssp lactis MG1363. La chromatographie RP-FPLC a également montré des différences entre les peptides libérés à partir de la caséine $\alpha_{s 1}$ par P1, P2 et P3.

\section{Lactococcus lactis / protéinase intracellulaire}

\section{INTRODUCTION}

To date, the most extensively studied proteolytic enzymes of lactic acid bacteria (LAB) are cell envelope-associated (CEP) proteinases and intracellular aminopeptidases. Oligopeptidases (PepO, PepF) which do not hydrolyze casein are also quite well characterized (see Monnet et al, 1994; Fox et al, 1995; Law and Haandrikman, 1996).

Intracellular caseinolytic activity comprises a marked portion of the total proteolytic activity of $\mathrm{prt}^{+}$and prt lactococci (Muset et al, 1989; Crow et al 1993a; Stepaniak and Fox, 1995). Westhoff et al (1971) separated four caseinolytic fractions from the intracellular material of slow acidproducing, presumably prt variant, of Lactococcus lactis subsp lactis. Ohmiya and Sato (1975) found only one proteinase in the intracellular fraction from $L$ cremoris subsp cremoris. Likewise, Muset et al (1989) found one principal intracellular proteinase in the prt variant of $L$ lactis subsp lactis NCDO 763. However, Akuzawa et al (1990) identified several intracellular endopeptidases, with or without caseinolytic activity, from L lactis subsp lactis IAM 1198. Work by Desmazeaud and Zevaco (1976) and Muset et al (1989) indicates that the proteolytic system of lactococci may, in addition to the caseinolytic proteinases and typical oligopeptidases (which hydrolyze various oligopeptides but not proteins), contains endopeptidases with relatively high activity on oligopeptides and low activity on casein.

Generally, intracellular turnover of proteins and peptides is an indispensable function of all living cells (Orlowski, 1990; Hilt and Wolf, 1996). Orlowski (1990) proposed that degradation of intracellular proteins is initiated by a ca $700 \mathrm{kDa}$ multicatalytic proteinase complex (MPC), while the function of intracellular endopeptidases, including prolyendopeptidases and oligopeptidases, is a further hydrolysis of released by MPC oligopeptides. MPC (termed also proteasomes) were well studied in eukaryotic cells but simpler MPC were also found in archaebacteria (Orlowski, 1990; Hilt and Wolf, 1996).

CEP and lactococcal oligopeptidase probably contribute to secondary proteolysis during cheese ripening by degrading peptides released by chymosin (Fox et al, 1995). Intracellular lactococcal proteinase was detected by an immunological technique in Gouda cheese ripened for 1 month (Akuzawa and Yokoyama, 1993). However, the significance of intracellular caseinolytic proteinases from $L A B$ for cheese ripening remains unknown.

Some of the principal intracellular lactococcal proteinases which have been char- 
acterized to various degrees (Westhoff et al, 1971; Ohmiya and Sato, 1975; Muset et al, 1989; Akuzawa et al, 1994; Akuzawa and Okitani, 1995) showed differences in general properties (table I), indicating a complex intracellular proteolytic system in lactococci. We reported that cytoplasm of L lactis subsp lactis MG1363 contains caseinolytic fractions separable by anionexchange chromatography (Stepaniak and Fox, 1995). The objective of this study was to characterize the major intracellular proteinases from this microorganism.

\section{MATERIALS AND METHODS}

\section{Microorganism}

Plasmid-free $L$ lactis subsp lactis MG1363 and its parental strain, $\mathrm{prt}^{+} L$ lactis subsp lactis 712 , were from the culture collection of the Department of Microbiology, University College, Cork (Ireland). The microorganisms were cultivated for $14 \mathrm{~h}$ at $30^{\circ} \mathrm{C}$ ( $1 \%$ inoculum; final $\left.\mathrm{pH}, \mathrm{ca} 5.0\right)$ in $\mathrm{M} 17$ broth (Merck, Darmstadt, Germany) supplemented with $0.5 \%$ glucose. The harvested cells were washed briefly in acetate-phosphate buffer, $\mathrm{pH} 6.4$, and then incubated for $30 \mathrm{~min}$ at $30^{\circ} \mathrm{C}$, with shaking, in $50 \mathrm{mmol} / \mathrm{L}$ Tris- $\mathrm{HCl}$ buffer, $\mathrm{pH} 7.5$, to release cell envelope-associated crude proteinase (Crow et al, 1993b). The procedure of Crow et al (1993b) was used to prepare intracellular fractions from lysozyme/mutanolysin-treated cells of $L$ lactis subsp lactis MG1363.

\section{Determination of cell yield}

A cell suspension $(2 \mathrm{~mL})$ was deposited by filtering on a $0.22 \mu \mathrm{m}$ pre-weighted filter, washed with water, freeze-dried and the weight of dried cells determined.

\section{Casein and peptide substrates}

Fluorescent casein was prepared by the method of Twinning (1984) and freeze-dried. $\alpha_{51}$ - and $\beta$-Caseins were prepared by urea fractionation and purified on DEAE-cellulose (Fox and Guiney, 1972) using a $\mathrm{NaCl}$ gradient $(0-0.5 \mathrm{~mol} / \mathrm{L})$ in phosphate buffer containing $4.5 \mathrm{~mol} / \mathrm{L}$ urea and $10 \mathrm{mmol} / \mathrm{L}$ mercaptoethanol. $\alpha_{s 1}$-Casein $1157-164$ was synthesized at the Biotechnology Centre, University of Oslo (Norway), using a Model 431 A peptide synthesizer (Applied Biosystems Inc, San Jose, CA, USA).

\section{Isolation of intracellular proteinases}

The yield of $L$ lactis subsp lactis MG1363 cells was $1.35 \mathrm{~g}$ of dry matter per litre. Proteolytic enzymes were isolated from the cytoplasmic fraction using a five-step purification procedure.

Step 1: Anion-exchange chromatography. The cytoplasmic fraction obtained from cells harvested from $20 \mathrm{~L}$ of culture was first applied to a column $(2.1 \times 75 \mathrm{~cm})$ of DEAE-cellulose equilibrated with $20 \mathrm{mmol} / \mathrm{L}$ phosphate buffer, $\mathrm{pH} 6.5$. The proteins were eluted at a flow rate of $18 \mathrm{~mL} / \mathrm{h}$ with a linear $\mathrm{NaCl}$ gradient from 0.1 to $0.6 \mathrm{~mol} / \mathrm{L}$. The fractions with strong caseinolytic activity were pooled, dialyzed for $24 \mathrm{~h}$ against $5 \mathrm{mmol} / \mathrm{L}$ phosphate buffer, $\mathrm{pH} 7.0$, and concentrated by freeze drying.

Step 2: Gel filtration chromatography. Caseinolytic fractions from chromatography on DEAEcellulose were redissolved in a small volume of

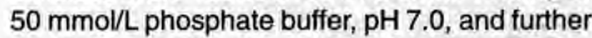
purified by gel filtration chromatography on Sephacryl 200 (column size $2.1 \times 73 \mathrm{~cm}$ ) equilibrated with $50 \mathrm{mmol} / \mathrm{L}$ phosphate buffer, $\mathrm{pH} 7.0$, containing $0.15 \mathrm{~mol} / \mathrm{L}$ of $\mathrm{NaCl}$. Elution with the same buffer was at the flow rate of $12 \mathrm{~mL} / \mathrm{h} ; 3 \mathrm{~mL}$ fractions were collected.

Step 3: Cation-exchange chromatography. The pooled fractions from gel filtration were further purified by chromatography on CM-cellulose (column size $1.5 \times 35 \mathrm{~cm}$ ). The column was washed with $20 \mathrm{mmol} / \mathrm{L}$ acetate buffer, $\mathrm{pH} 5.25$, and a linear salt gradient ( 0.1 to $0.4 \mathrm{~mol} / \mathrm{L}$ of $\mathrm{NaCl}$ ) was used to elute adsorbed protein. The flow rate was $10 \mathrm{~mL} / \mathrm{h}$ and $2 \mathrm{~mL}$ fractions were collected, dialyzed and concentrated by freezedrying.

Step 4: The fourth purification step involved chromatography either on hydroxyapatite or Phenyl Sepharose; the pooled proteolytic fractions from the first three purification steps were divided into two portions. One portion was chromatographed on hydroxyapatite (column size $0.21 \times 10 \mathrm{~cm}$ ) at a flow rate of $12 \mathrm{~mL} / \mathrm{h}$ using a linear potassium phosphate buffer gradient, 0.01 to $0.4 \mathrm{~mol} / \mathrm{L}, \mathrm{pH} 6.0 ; 1 \mathrm{~mL}$ fractions were collected. The second portion was purified on Phenyl Sepharose (column size $1.6 \times 10 \mathrm{~cm}$ ) using a linear ammonium sulphate gradient ( 1.7 to 0 
$\mathrm{mol} / \mathrm{L}$ ) in $50 \mathrm{mmol} / \mathrm{L}$ phosphate buffer, $\mathrm{pH} 7.0$, at a flow rate of $0.5 \mathrm{~mL} / \mathrm{min}$; fractions $(1 \mathrm{~mL}$ ) with high proteolytic activity were collected. Better separation of nonenzymatic and caseinolytic proteins was obtained by chromatography on Phenyl Sepharose.

Step 5: Secondary ion-exchange chromatography. Active fractions from Phenyl Sepharose were finally purified on a ready-packed MonoQ column HR 5/5 (Pharmacia Biotech, Uppsala, Sweden). The proteins were eluted using a $\mathrm{NaCl}$ gradient in $20 \mathrm{mmol} / \mathrm{L}$ Bis-Tris propane buffer, $\mathrm{pH} 6.5$, at a flow rate of $0.75 \mathrm{~mL} / \mathrm{min}$. The centers of the protein peaks were collected manually. The first three purification steps were performed at $4{ }^{\circ} \mathrm{C}$, but chromatography on hydroxyapatite, Phenyl Sepharose and MonoQ was at room temperature on columns connected to a fast protein liquid chromatography system (FPLC; Pharmacia-Biotech).

\section{Determination of enzymatic activities}

Caseinolytic activity was measured routinely in $50 \mathrm{mmol} / \mathrm{L}$ phosphate buffer, $\mathrm{pH} 6.0$, by the method of Twinning (1984) using fluorescent casein $(0.5 \%)$ as substrate. Activity in chromatographic fractions was measured after incubation at $30{ }^{\circ} \mathrm{C}$ for $20 \mathrm{~h}$ or after $6 \mathrm{~h}$ during characterization of the enzymes. The incubation mixture contained $0.02 \% \mathrm{NaN}_{3}$. The purified enzymes were diluted to approximately the same activity at $\mathrm{pH} 6.0$ and $30^{\circ} \mathrm{C}$. The fluorescence of the control sample (to which purified enzyme was added after incubation of substrate) was less than $5 \%$ of that measured in the enzyme-containing sample after $6 \mathrm{~h}$ of incubation. Activity expressed as an increase in arbitrary fluorescence units was measured using a fluorescence HPLC monitor (Shimadzu corporation, Kyoto, Japan).

PepN and PepX aminopeptidase activities on Leu-pNA and Arg-Pro-pNA, respectively, were measured as described by Stepaniakand Fox (1995).

\section{Protein content}

Protein content was measured by the method of Bradford (1976).

\section{Electrophoresis}

Urea-polyacrylamide gel electrophoresis (UreaPAGE) was used to separate peptides released from $\alpha_{s_{1}}$ - or $\beta$-caseins by purified proteinases. Electrophoresis was performed by the method of Andrews (1983); gels were stained as described by Blakesley and Boezi (1977). SDS-PAGE was performed in Mini-Protean II electrophoresis cell (Bio-Rad, Herculers, CA, USA) using the procedure recommended by the manufacturer.

\section{Molecular mass determination}

The molecular mass $\left(M_{8}\right)$ was determined by SDS-PAGE and gel filtration on a TSK 3000 SW column $(60 \mathrm{~cm} \times 7.5 \mathrm{~mm}$, TosoHaas, Stuttgart, Germany).

\section{Electroblotting and $\mathrm{N}$-terminal analysis}

Electroblotting and staining of peptides released from $\beta$-casein by intracellular proteinases and separated by urea-PAGE was performed as described by Singh et al (1995). Some peptides extracted from the membrane used for electroblotting were partially sequenced at National Food Biotechnology Centre, University College, Cork (Ireland) by Edman degradation on an automated pulsed liquid-phase protein-peptide sequencer (model 477A; Applied Biosystems Inc, Foster City, CA, USA). Liberated amino acids were detected as their phenylthiohydantoin derivatives using a model $120 \mathrm{~A}$ analyzer (Applied Biosystems).

\section{Reverse-phase chromatography}

Reverse-phase chromatography with PepRC HR5/5 column (Pharmacia) was used to separate $1 \%$ trifluoroacetic acid (TFA)-soluble peptides released from $\alpha_{s 1}$-casein by the purified proteinases and to determine degradation of $\alpha_{51}$ * casein fragment $157-164\left(\alpha_{31}-\mathrm{CN}\right.$ f157-164). Chromatographic conditions were as described by Stepaniak and Fox (1995).

\section{Effect of $\mathrm{pH}$, temperature and inhibitors}

Effect of $\mathrm{pH}$ at $30^{\circ} \mathrm{C}$ was measured using universal buffer (Dawson et al, 1969). The effect of temperature and inhibitors was measured using phosphate buffer, $\mathrm{pH}$ 6.0. Proteinases were incubated with inhibitors at $\mathrm{pH} 6.0$ at room temperature. After $10 \mathrm{~min}$, the inhibitor-enzyme buffer mixture was diluted ten-fold with buffered fluorescein-labelled casein so that the final con- 
centration of substrate was $0.5 \%$ and the final concentration of phosphate buffer was $50 \mathrm{mmo} / \mathrm{L}$.

\section{RESULTS AND DISCUSSION}

\section{Purification and molecular mass $\left(M_{\mathrm{s}}\right)$}

Chromatography of the cytoplasm from $L$ lactis subsp lactis MG1363 on DEAE-cellulose resolved two major and two minor protein peaks with caseinolytic activity (fig 1). Gel filtration on Sephacryl 200 resolved the first proteolytic fraction into two major and one minor peak (fig 2A), while the second caseinolytic fraction was only partially resolved (fig $2 \mathrm{~B}$ ). As shown in figures 1 and 2 , the main proteolytic fractions were denoted as proteinases P1, P2 and P3. A substantial amount of noncaseolytic proteins were removed from each of the three proteinases by chromatography on $\mathrm{CM}$ cellulose, Phenyl-Sepharose or hydroxyapatite. One minor peak was separated from $\mathrm{P} 1, \mathrm{P} 2$ and $\mathrm{P} 3$ by chromatography on $\mathrm{CM}$-cellulose. Traces of proteolytic activity were separated from P1, P2 and P3 by

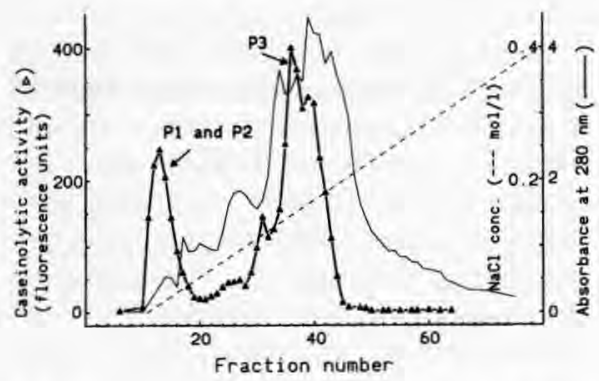

Fig 1. Separation of caseinolytic activity in the cytoplasm of $L$ lactis subsp lactis MG1363 on DEAE-cellulose. Activity was measured on fluorescent casein. P1, P2 and P3: proteinases 1, 2 and 3 , respectively.

Fractionnement de l'activité caséolytique dans le cytoplasme de L lactis ssp lactis MG1363 sur cellulose DEAE. L'activité a été mesurée sur une caséine fluorescente. P1, P2 et P3 : protéinases 1,2 et 3 respectivement. chromatography on Phenyl-Sepharose (data not shown) and in the case of P1, a minor proteolytic peak was identified in the eluate from MonoQ (fig 3). The three proteinases were eluted from MonoQ column at different $\mathrm{NaCl}$ concentrations (fig 3 ).

Following purification by the five-step procedure, proteinases $\mathrm{P} 1, \mathrm{P} 2$ and $\mathrm{P} 3$ were not homogeneous by SDS-PAGE, although the specific activity of P1 and P2 increased markedly (table I) and the three enzymes were free from PepN and PepX activities. The purification procedure was repeated with similar results. SDS-PAGE showed one major and three minor protein bands in $\mathrm{P} 1$, one major and one minor band in P2 and one major and two minor bands

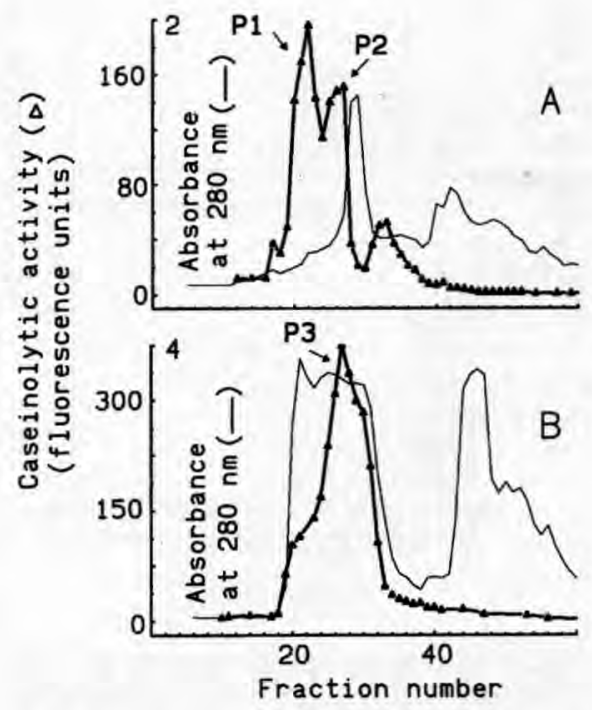

Fig 2. Separation of proteinases $P 1$ from $P 2$ (A) and further purification of proteinase $\mathrm{P} 3(\mathrm{~B})$ from the cytoplasm of $L$ lactis subsp lactis MG1363 by chromatography of the proteolytic fraction from DEAE-cellulose on Sephacryl 200.

Séparation des protéinases $P 1$ de $P 2$ (A) et purification ultérieure de la protéinase $P 3(B) d u$ cytoplasme de L lactis ssp lactis MG1363 par chromatographie sur Sephacryl 200 des fractions protéolytiques obtenues sur cellulose $D E A E$ (fig 1). 
in P3. No protein bands of $M_{\mathrm{s}}>67 \mathrm{kDa}$ were present in the electrophoregrams of $P 1, P 2$ and $P 3$. Comparison of the $M_{s}$ of the major protein band on SDS-PAGE electrophoregram of proteinase $P 1$ with the $M_{s}$ of

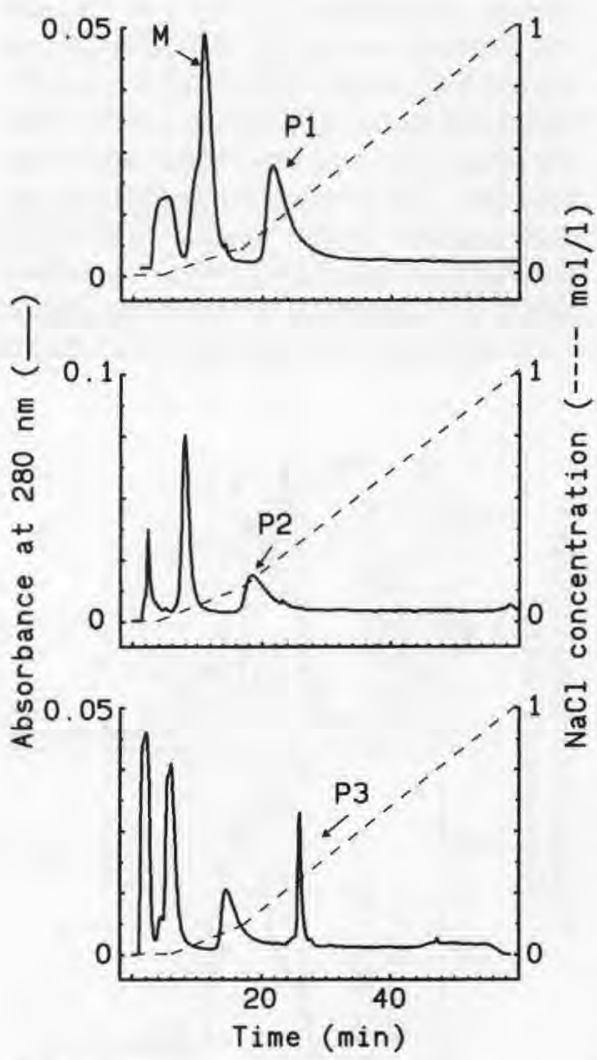

Fig 3. Final (fifth step) purification of proteinases $\mathrm{P} 1, \mathrm{P} 2$ and $\mathrm{P} 3$ from L lactis subsp lactis MG1363 by secondary ion-exchange chromatography on MonoQ. Approximately $30 \%$ of each enzyme recovered from purification on Phenyl Sepharose was loaded on the column. M: minor proteolytic fraction.

Purification finale ( $5^{\circ}$ étape) des protéinases $P 1$, $P 2$ et $P 3$ de L lactis ssp lactis MG1363 par chromatographie d'échange d'anions secondaire sur monoQ. Environ $30 \%$ de chaque enzyme récupérée sur la phényl sépharose ont été chargés sur la colonne. $M$ : fraction protéolytique mineure. the highest proteolytic fraction collected from the gel filtration column indicated that the enzyme was a dimer. The molecular masses established in the same way for P2 and P3 indicated that these enzymes were monomers (table I).

In agreement with other reports (Westhoff et al, 1971; Muset et al, 1989; Akuzawa et al, 1990; Stepaniak and Fox, 1995), the cytoplasm of Lactococcus contains several proteinases which are eluted from anion exchangers between 0 and $0.4 \mathrm{~mol} / \mathrm{L}$ of $\mathrm{NaCl}$. Akuzawa et al (1990) separated three major and two minor caseinolytic fractions from the cytoplasm of $L$ lactis subsp lactis IAM 1198 by chromatography on DEAE-cellulose. The caseinolytic fractions were further resolved by gel filtration, yielding proteinases which differed markedly in molecular mass and belonged to different biochemical classes. Serine and cysteine proteinases in the fraction eluted from DEAE-cellulose at ca $0.05 \mathrm{~mol} / \mathrm{L}$ of $\mathrm{NaCl}$ were isolated and characterized by Akuzawa et al (1994) and Akuzawa and Okitani (1995) (table I). Muset et al (1989) found two major proteinases in $\mathrm{prt}^{+} \mathrm{L}$ lactis subsp lactis NCDO 763, but in case of the prt variant, proteinase activity eluted from a MonoQ column before the $\mathrm{NaCl}$ gradient was markedly reduced. According to Westhoff et al (1971), Ohmiya and Sato (1975) and Akuzawa and Okitani (1995), anion exchange and gel filtration chromatography (see table I) were sufficient to purify the proteinases to homogeneity. The data from chromatography (figs 1-3) and SDS-PAGE indicate that the cytoplasm from $L$ lactis subsp lactis MG1363 contained several major and minor proteinases or that the intracellular proteinases were susceptible to autolysis. Together with proteinase P1, P2 and P3 from this study, intracellular lactococcal proteinases represent a group of enzymes of markedly diverse molecular masses (table I). As established by gel filtration $M_{s}$, of proteinase $P 1$, proteinase LLP- $\| C_{2}$ and the proteinase reported by 
Table I. General characteristics of lactococcal intracellular proteinases.

Caractéristiques générales des protéinases intracellulaires de Lactococcus.

\begin{tabular}{|c|c|c|c|c|c|c|c|c|}
\hline & $\begin{array}{c}P 1 \\
\text { (this study) }\end{array}$ & $\begin{array}{c}P 2 \\
\text { (this study) }\end{array}$ & $\begin{array}{c}P 3 \\
\text { (this study) }\end{array}$ & $\begin{array}{c}L L P-\| C_{2} \text { from } \\
\text { L lactis subsp } \\
\text { lactis IAM 1198 } \\
\text { (Akuzawa \& } \\
\text { Okitani, 1995) }\end{array}$ & $\begin{array}{c}\text { LLP-IIC from } \\
\text { L lactis subsp } \\
\text { lactis IAM } 1198 \\
\text { (Akuzawa } \\
\text { et al, 1994) }\end{array}$ & $\begin{array}{c}\text { From L lactis } \\
\text { subsp } \\
\text { cremoris H61 } \\
\text { (Ohmiya \& } \\
\text { Sato, 1975) }\end{array}$ & $\begin{array}{c}\text { From L lactis } \\
\text { subsp lactis } \\
\text { NCDO } 763 \\
\text { (Muset } \\
\text { et al, 1989) }\end{array}$ & $\begin{array}{c}\text { From L lactis } \\
\text { subsp lactis } \\
\text { No } 3 \\
\text { (Westhoff } \\
\text { et al, 1971) }\end{array}$ \\
\hline Type & Metallo & Serine & Serine & Cysteine & Serine & Metallo & Metallo & * \\
\hline $\begin{array}{l}\text { Ms }(\mathrm{kDa}) \text { by gel filtration } \\
\text { by SDS-PAGE } \\
\text { sedimentation velocity }\end{array}$ & $\begin{array}{r}124 \\
66\end{array}$ & $\begin{array}{l}62 \\
68\end{array}$ & $\begin{array}{l}47 \\
52\end{array}$ & $\begin{array}{l}12 \\
12\end{array}$ & $\begin{array}{c}140 \\
67\end{array}$ & $\begin{array}{l}140 \\
\text { ND }\end{array}$ & $\begin{array}{l}93 \\
\text { ND }\end{array}$ & 3.3 \\
\hline pH optimum & 7.0 & 7.5 & 7.5 & $5.5-6.0$ & $6.0-6.5$ & 7.0 & 7.5 & 7.6 \\
\hline Temp optimum $\left({ }^{\circ} \mathrm{C}\right)$ & 35 & 45 & 45 & 30 & $30-35$ & 30 & 45 & ND \\
\hline $\begin{array}{l}\text { Purification by successive } \\
\text { chromatography on: }\end{array}$ & \multicolumn{3}{|c|}{$\begin{array}{c}\text { DEAE-cellulose, Sephacryl } 200 \text {, } \\
\text { CM-cellulose, Phenyl Sepharose, } \\
\text { MonoQ }\end{array}$} & $\begin{array}{l}\text { DEAE-cellulose, } \\
\text { Sephadex } \\
\text { G-100 }\end{array}$ & $\begin{array}{c}\text { DEAE-cellulose, } \\
\text { Sephadex } \\
\text { G-100 } \\
\text { P-cellulose, } \\
\text { DEAE-cellulose, } \\
\text { TSK-G } 3000 \text { SW }\end{array}$ & $\begin{array}{l}\text { DEAE- } \\
\text { cellulose } \\
\text { Sephadex } \\
\text { G-200 }\end{array}$ & $\begin{array}{c}\text { MonoQ, } \\
\text { Superose } 12\end{array}$ & $\begin{array}{l}\text { DEAE-Sephadex } \\
\text { Bio-Gel P-30 } \\
\text { Bio-Gel P10 }\end{array}$ \\
\hline Fold purification & 291 & 266 & 57 & 105 & 111 & 150 & 12 & 160 \\
\hline
\end{tabular}

* Not sensitive to $p$-hydroxymercuribenzoate ( $p$-HMB); $M_{\mathrm{s}}$ : molecular mass; ND: not determined. 
Ohmiya and Sato (1975) were similar, but proteinase LLP-IIC 2 was classified as serine, while the other two enzymes were metalloproteinases (table I). Occurrence of the major low molecular mass proteinases reported by Westhoff et al (1971) and Akuzawa and Okitani (1995) were not confirmed by this study. Cultivation conditions may influence the concentration of intracellular lactococcal proteinases (Ohmiya and Sato, 1975) and, therefore, at the time of isolation different proteinases may occur as principal or minor enzymes. Proteasomes also hydrolyze caseins and these enzyme-complexes may be degraded to active subunits (Orlowski, 1990). It is warranted to determine if: 1) proteasomes occur in LAB; 2) some intracellular proteinases may be products of their degrada-

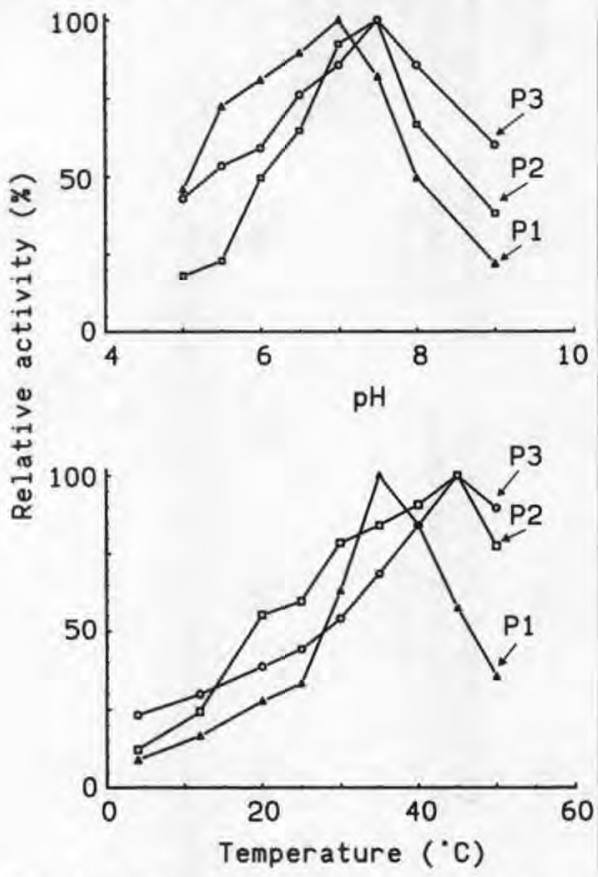

Fig 4. Effect of temperature and $\mathrm{pH}$ on the activity of cytoplasmic proteinases $\mathrm{P} 1, \mathrm{P} 2$ and P3 from L lactis subsp lactis MG1363.

Effet de la température et du pH sur l'activité des protéinases cytoplasmiques $P 1, P 2$ et $P 3$ de L lactis ssp lactis MG1363. tion; and 3) the function of intracellular proteinase corresponds to that of proteasomes in eukaryotic or mammalian cells.

\section{Effect of $\mathrm{pH}$ and temperature}

$\mathrm{P} 1$ differed from both $\mathrm{P} 2$ and $\mathrm{P} 3$ with respect to $\mathrm{pH}$ and temperature optima (table I, fig 4). However, P1, P2 and P3 and the proteinases studied earlier had, with the exception of proteinase LLP-IIC 2 , pH optima characteristic for neutral enzymes and temperature optima between 30 and $45{ }^{\circ} \mathrm{C}$ (table I). P2 was relatively somewhat more active at $\mathrm{pH} 5-5.5$ than $\mathrm{P} 1$ and $\mathrm{P} 3$, but all three enzymes showed marked activity at 12 and $50^{\circ} \mathrm{C}$. A low activation energy was characteristic of proteinase LLP-IIC 2 (Akuzawa and Okitani, 1995).

\section{Effect of inhibitors}

Results in table II indicate that proteinase $\mathrm{P} 1$ is a metalloenzyme while P2 and P3 are serine proteinases. However, both P2 and P3 were partially inhibited by metal chelators and $p$-hydroxymercuribenzoate at a concentration of $5 \mathrm{mmol} / \mathrm{L}$. Treatment of the proteinases with inhibitors at a concentration of $1 \mathrm{mmol} / \mathrm{L}$ gave less conclusive results. Metalo-, serine and cysteine proteinases were found in cytoplasm from lactococci (table I). Noncaseinolytic lactococcal endopeptidases (PepO, PepF) are metalloenzymes (Monnet et al, 1994; Stepaniak and Fox, 1995; Law and Haandrikman, 1996).

\section{Specificity of P1, P2 and P3 proteinases}

Urea-PAGE of $\beta$-casein hydrolysates show marked differences in the peptide patterns produced by the three intracellular proteinases from $L$ lactis subsp lactis MG1363 and the CEP from Lactococcus lactis subsp lactis 712 , but the differences between electrophoregrams of peptides released by the four enzymes from $\alpha_{s 1}$-casein are less 


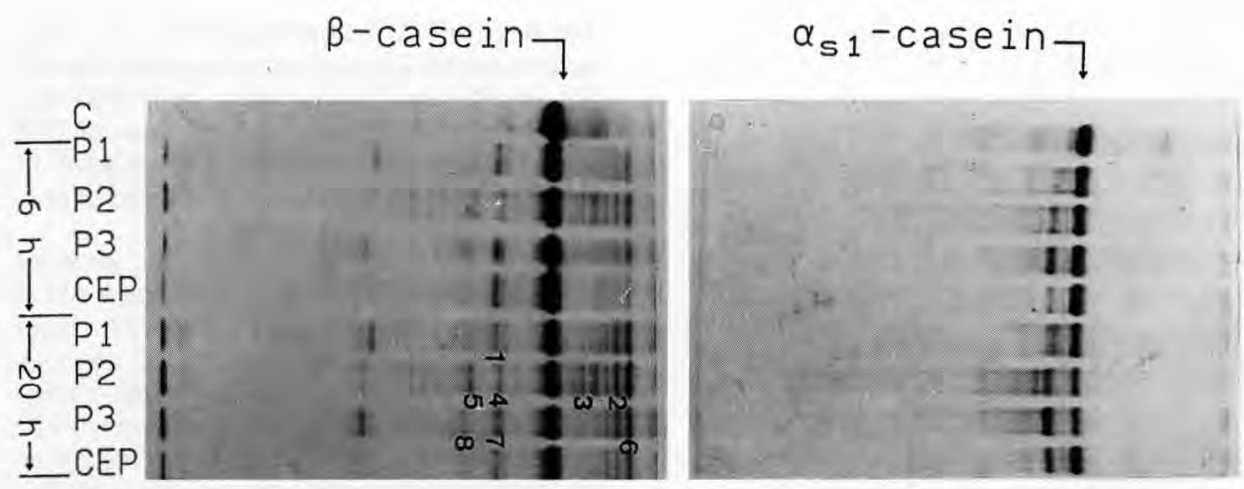

Fig 5. Urea-PAGE electrophoregrams of $\alpha_{s 1}$ - and $\beta$-casein incubated with proteinases P1, P2 and P3 from $L$ lactis subsp lactis MG1363 and crude cell envelope-associated proteinase (CEP) from $L$ lactis subsp lactis 712 for 6 or $20 \mathrm{~h}$. C: control incubated for $20 \mathrm{~h}$ without proteinases.

\begin{tabular}{|c|c|c|}
\hline Band & $\mathrm{N}$-terminal sequence & Position on $\beta$-casein \\
\hline 1: & Arg-Glu-Leu-Glu-Glu-Leu-Asn-X.. & $1-7-X \ldots$ \\
\hline 2: & Ala-GIn-Thr-GIn-Ser-X... & $53-57-X \ldots$ \\
\hline \multirow[t]{3}{*}{ 3: } & Contained 2 peptides: & \\
\hline & Lys-Ile-Glu-Lys-Phe-X... & $29-33-X . . . *$ \\
\hline & Ala-GIn-Thr-Gin-X ... & $53-56-X \ldots$ \\
\hline 4: & Arg-Glu-Leu-Glu-X... & $1-4-X \ldots$ \\
\hline 5: & Arg-Glu-Leu-Glu-X... & $1-4-X \ldots$ \\
\hline \multirow[t]{3}{*}{ 6: } & Contained 2 peptides: & \\
\hline & Asp-Lys-Ile-His-Pro-Phe-X... & $47-52-X \ldots$ \\
\hline & Ala-Gin-Thr-Gin-Ser-X... & $53-57-X \ldots$ \\
\hline 7: & Arg-Glu-Leu-Glu-Glu-Leu-Asn-X... & $1-7-X \ldots$ \\
\hline 8: & Arg-Glu-Leu-Glu-Glu-X... & $1-5-X \ldots$ \\
\hline
\end{tabular}

${ }^{*} \mathrm{~N}$-terminal sequence of $\gamma 1$-casein

Électrophorégramme urée PAGE des caséines $\alpha$ et $\beta$ incubées pendant 6 ou 20 heures avec les protéinases P1, P2 et $P 3$ de L lactis ssp lactis MG1363 ou les protéinases brutes associées à l'enveloppe cellulaire de L lactis ssp lactis 712 (CEP). C; témoin incubé 20 heures sans protéinase.

distinct (fig 5). Amino acid sequencing of some peptides released from $\beta$-casein showed that most of them were $\mathrm{N}$-terminal fragments of $\beta$-casein (fig 5). Reversephase (RP) FPLC chromatograms of TFAsoluble peptides released from $\alpha_{s 1}$-casein also indicated differences in the specificity of P1, P2 and P3 (fig 6).

Proteinases P1, P2, P3 and CEP hydrolysed (RP-FPLC chromatograms are not shown) $\alpha_{s 1}-C N$ f157-164, a minor peptide in the chymosin hydroly-

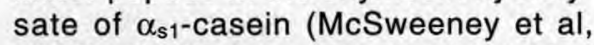
1993), which was not degradable by the lactococcal PepO (Stepaniak and Fox, 1995).

The intracellular metalloproteinase $\left(M_{s}\right.$ $49.5 \mathrm{kDa}$ by gel filtration) from $L$ lactis subsp lactis biovar diacetylactis characterized by Desmazeaud and Zevaco (1976) and Zevaco and Desmazeaud (1980) cleaved $\beta$-casein slowly at Pro ${ }_{186}-\mathrm{Ile}_{187}$ and $\mathrm{Ala}_{189}-\mathrm{Ph}_{190}$. The enzyme was identified in chromatographic fractions using oxidized insulin. It also slowly hydrolyzed $\alpha_{s 1}$ casein, but it rapidly degraded two $\beta$-casein-derived peptides and bradykinin. Its specificity was similar to that of thermolysin 


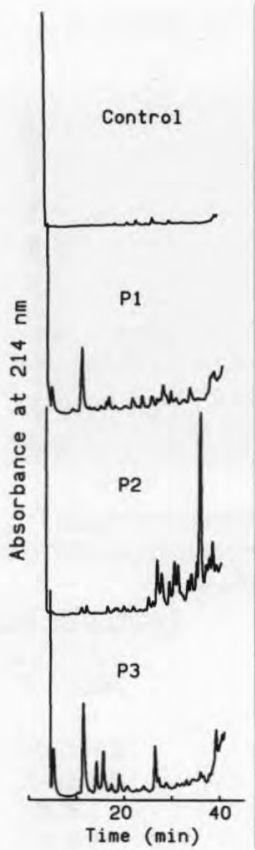

Fig 6. RP-FPLC chromatograms of $1 \%$ TFAsoluble peptides released from $\alpha_{s 1}$-casein by $P 1$, $\mathrm{P} 2$ and $\mathrm{P} 3$ from $L$ lactis subsp lactis MG1363. C: control as in figure 5. A large peak of TFA eluted at the beginning and a large peak of undigested $\alpha_{s 1}$-casein eluted at the end of acetonitrile gradient are not shown.

Chromatogrammes RP-FPLC de peptides solubles dans l'acide tri-fluoroacétique à $1 \%$ et libérés de la caséine $\alpha_{s 1}$ par $P 1, P 2$ ou $P 3$ à partir de $L$ lactis ssp lactis MG1363. C: témoin, comme sur la figure 5. Un large pic d'acide tri-fluoroacétique élué au début ainsi qu'un large pic de caséine $\alpha_{s 1}$ non hydrolysée éluée à la fin du gradient d'acétonitrile ne sont pas montrés.

Table II. Effect of specific inhibitors on the activity of intracellular proteinases P1, P2 and P3 from L lactis subsp lactis MG1363.

Effet des inhibiteurs spécifiques sur l'activité des protéinases intracellulaires $P 1, P 2$ et $P 3$ de L lactis ssp lactis MG 1363.

\begin{tabular}{lccc}
\hline Inhibitor $(5 \mathrm{mmol} / \mathrm{L})$ & $\begin{array}{c}P 1 \\
\text { Relative }\end{array}$ & $\begin{array}{c}P 2 \\
\text { activity }\end{array}$ & $\begin{array}{c}P 3 \\
(\%)\end{array}$ \\
\hline Control & 100 & 100 & 100 \\
PMSF* & 78 & 8 & 14 \\
EDTA & 21 & 90 & 67 \\
o-Phenanthroline & 35 & 38 & 30 \\
p-HMB** & 72 & 41 & 30 \\
lodoacetic acid & 73 & 10 & 19 \\
\hline
\end{tabular}

or $70 \mathrm{kDa}$ lactococcal PepO. The proteinase characterized by Muset et al (1989) (table I) also slowly hydrolyzed $\beta$-casein. The specificity of proteinases studied by Westhoff et al (1971) and Muset et al (1989) on oxidized insulin chain B was similar to that of thermolysin.

\section{CONCLUSION}

The cytoplasm of prt, plasmid-free $L$ lactis subsp lactis MG1363 contains a complex caseinolytic system comprising proteinases of apparently different specificity. The three major proteinases (P1, P2 and 
P3) are quite active at the $\mathrm{pH}$ and temperature of ripening cheese. Assessment of the ability of P1, P2 and P3 to hydrolyze $\beta-C N$ f193-209 is warranted because this peptide is resistant to degradation by chymosin, lactococcal CEP (Exterkate et al, 1995) and lactococcal, $70 \mathrm{kDa}$ PepO (Stepaniak et al, 1996). Immunological studies may reveal if the intracellular proteinases P1, P2 and $\mathrm{P} 3$ are related to the minor proteolytic fractions detected during the purification process or with intracellular lactococcal proteinases studied by other authors.

\section{ACKNOWLEDGMENTS}

The project was funded in part from EU structural funds from its Food Sub-Programme of the Industry Programme:

\section{REFERENCES}

Akuzawa R, Yokoyama K (1993) Behavior of a proteinase, indicated low activation energy from Lactococcus lactis ssp lactis during cheese ripening. Jpn $J$ Dairy Food Sci 42, 145-151

Akuzawa R, Okitani A (1995) Purification and characterization of a cysteine proteinase with low activation energy from Lactococcus lactis spp lactis IAM 1198. $J$ Dainy Sci 78, 2609-2616

Akuzawa R, Yokoyama K, Matsuishi M, Okitani A(1990) Isolation and partial characterization of intracellular proteinases in Lactococcus lactis ssp lactis IAM 1198. J Dairy Sci 73, 3385-3392

Akuzawa R, Yagi N, Kimura M, Okitani A (1994) Purification and characterization of a serine proteinase from Lactococcus lactis spp lactis IAM 1198. Anim Sci Technol [Jpn] 65, 22-32

Andrews AT (1983) Proteinases in nomal bovine milk and their action on caseins. J Dairy Res 50, 45-55

Blakesley RW, Boezi JA (1977) A new staining technique for proteins in polyacrylamide gels using Coomassie Brilliant Blue G250. Anal Biochem 82, 580-582

Bradford MM (1976) A rapid and sensitive method for the quantitation of microgram quantities of protein utilizing the principle of protein-dye binding. Anal Biochem 72, 248-254

Crow VL, Coolbear T, Holland R, Pritchard GG, Martley F (1993a) Starters as finishers; starter properties relevant to cheese ripening. Int Dairy J 3, 423-460

Crow VL, Holland R, Coolbear T (1993b) Comparison of subcellular fractionation methods for Lactococcus lactis ssp lactis and Lactococcus lactis ssp cremoris. Int Dairy J 3, 599-611

Dawson RMC, Elliott D, Elliott WH, Jones KM (1969) Data for Biochemical Research. Clarendon Press, Oxford, UK
Desmazeaud MJ, Zevaco C (1976) General properties and substrate specificity of an intracellular neutral protease from Streptococcus diacetylactis. Ann Biol Biochim Biophys 16, 851-868

Exterkate FE, Alting AC, Slangen CJ (1995) Conversion of $\alpha_{s 1}$-casein- (24-199)-fragment and $\beta$-casein under cheese conditions by chymosin and starter peptidases. System Appl Microbiol 18, 7-12

Fox PF, Guiney J (1972) A procedure for partial fractionation of the $\alpha_{s 1}$-casein complex. J Dairy Res $39,49-53$

Fox PF, Singh TK, McSweeney PLH (1995) Biogenesis of flavour compounds in cheese. In: Chemistry of Structure-Function Relationships in Cheese (EL Malin, MH Tunick, eds) Plenum Press, New York, USA

Hilt W, Wolf D (1996) Proteasomes: destruction as a programme. Trends Biochem Sci 21, 96-102

Law J, Haandrikman A (1996) Proteolytic enzymes of lactic acid bacteria. Int Dairy $J$ (in press)

McSweeney PLH, Olsen NF, Fox PF, Healy A, Hojrup P (1993) Proteolytic specificity of chymosin on bovine

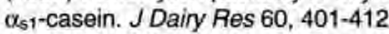

Monnet V, Nardi M, Chopin A, Chopin MC, Gripon JC (1994) Biochemical and genetic characterization of PepF, an oligopeptidase from Lactococcus lactis. I Biol Chem 269, 32070-32076

Muset G, Monnet V, Gripon JC (1989) Intracellular proteinase of Lactococcus lactis ssp lactis NCDO 763. I Dairy Res 56, 765-778

Onmiya K, Sato $Y$ (1975) Purification and properties of intracellular proteinase from Streptococcus cremoris. Appl Microbiol 30, 738-745

Orlowski M (1990) The multicatalytic proteinase complex, a major extralysosomal proteolytic system. Biochemistry 29, 10289-10297

Singh TK, Fox PF, Healy A (1995) Water-soluble peptides in Cheddar cheese. Isolation and identification of peptides in the diafiltration retentate of the watersoluble fraction. J Dairy Res 62, 629-640

Stepaniak L, Fox PF (1995) Characterization of the principal intracellular endopeptidase from Lactococcus lactis subsp lactis. Int Dairy J 5, 699-713

Stepaniak L, Gobbetti M, Søhaug T, Fox PF, Højrup P (1996) Peptides inhibitory to endopeptidase and aminopeptidase from Lactococcus lactis ssp lactis MG1363, released by chymosin, trypsin and chymotrypsin from bovine $\beta$-casein. $Z$ Lebens Unters Forsch 202, 329-333

Twinning S (1984) Fluorescein isothiocyanate-labeled casein assay for proteolytic enzymes. Anal Biochem 143, 30-34

Westhoff DC, Cowman RA (1971) Substrate specificity of the intracellular proteinase from a slow acid producing mutant of Streptococcus lactis. I Dairy Sci 54, 1265-1269

Westhoff DC, Cowman RA, Swaisgood HE (1971) Characterization of an intracellular proteinase of a slow acid producing mutant of Streptococcus lactis. J Dain Sci $54,1259-1264$

Zevaco C, Desmazeaud MJ (1980) Hydrolysis of $\beta$-casein and peptides by intracellular neutral protease of Streptococcus diacetylactis. J Dairy Sci 63, 15-24 